\title{
O uso político dos cadáveres na França da primeira metade do século XIX
}

\author{
Isabel Lustosa \\ Fundação Casa de Rui Barbosa \\ Rio de Janeiro, RJ, Brasil \\ isabellustosa@uol.com.br
}

Fureix, Emmanuel. La France des larmes: deuils politiques à l'âge romantique, 1814-1840. Preface d'Alain Corbin. Seyssel: Éditions Champ Vallon, 2009. (Époques)

Se há muitas maneiras de se contar a mesma história, Emmanuel Fureix achou a mais completa possível para apresentar o espírito que marcou a Restauração (1814-1830) e o reinado de Luis Felipe na França (1830-1848), ou para usar um conceito que unifica politicamente o período: o tempo da monarquia censitária. Diz o autor que "a emoção do luto participa inegavelmente da socialização política dos indivíduos" e, de fato, ao investigar formatos, paixóes e interesses que orientaram as cerimônias fúnebres durante aqueles 26 anos, Fureix revelou o panorama mais completo das tensóes e das mudanças que caracterizariam aquela fase da história francesa. Ao mesmo tempo, ele nos apresenta a Paris do início do século XIX como uma metrópole popular e guerreira, onde a rua, através das cerimônias fúnebres, foi, gradativamente, se tornando o teatro de todas as agitaçóes: cortejos de estudantes, manifestaçôes de operários e de desempregados, desfiles patrióticos e militares, solenidades civis de natureza política etc.

Efeito ainda da Grande Revolução, o período que sucedeu à queda de Bonaparte foi marcado pela falta de uma base sólida sobre a qual se estabilizasse a vida política da naçáo. $\mathrm{O}$ restabelecimento dos Bourbon no trono, afastados dele há mais de 22 anos, passou pela retomada dos antigos ritos da monarquia já esquecidos e em desuso. $\mathrm{O}$ ritual pretendia confirmar o triunfo do estado social aristocrático. Feito de distinçôes e baseado na ideia de uma estabilidade e de uma eternidade fictícias, o ritual estabelecia os espaços de partilha e de exclusão de uma sociedade "anacrônica, organicista, de hierarquias exacerbadas e centrada sobre o corpo do rei". Foi preciso um grande esforço para recriar a pompa dos funerais monárquicos, com todos os degraus da nobreza e suas convençôes e, inclusive, colocar o povo de novo em seu lugar: como mero espectador, náo mais ator.

$\mathrm{O}$ ano de 1814 marca a emergência de uma onda de espiritualização patrocinada pelo ressurgimento de uma Igreja Católica militante. Desse cenário fazem parte as cerimônias de sepultamento de Luis XVI e de Maria Antonieta. Retirar da cova quase anônima em que foram depositados o rei e a rainha agora exaltados como mártires foi uma missão a que se dedicou Luis XVIII. Tratava-se de corrigir o pecado da naçáo francesa contra os Bourbon, dando aos reis decapitados o enterro merecido que lhes fora interdito pela Revolução. Mas tratava-se também de não se referir às circunstâncias em que se deram a queda e a morte do rei. A Revoluçáo era um assunto proibido em um ambiente em que os Bourbon voltavam com a promessa de obedecer à Carta e de reinar para todos, produzindo a reconciliaçáo da França. Assim, para os que se ocupavam desses rituais, tratava-se de escolher "que tradiçôes reativar sem ultrajar a história contemporânea, quais concessôes fazer à modernidade, sem destruir os fundamentos duma monarquia sagrada”. Ao analisar os funerais da Restauraçáo, Fureix demonstra como eles foram um combinado "de arranjos sutis, capazes de integrar discretamente as mudanças institucionais". 
A arte da morte, o "morrer como um Bourbon" - na santidade, no martírio — , se torna formidável instrumento de legitimaçáo, que tem a possibilidade de se reatualizar por ocasião do assassinato do duque de Berry (1821). Os relatos de suas últimas palavras, amplamente divulgadas, perdoando o assassino e pedindo, antes do médico, um padre, realçavam a relaçáo estreita entre o trono e o altar. Nessa representação, a imagem da dor é encarnada pela filha de Luis XVI, a duquesa de Angoulême, utilizada como uma espécie de alegoria dinástica em todas as cerimônias fúnebres. A família real era a primeira família católica da França e com sua obediência aos ritos religiosos confirmava o papel político e estratégico da Igreja Católica, detentora da autoridade sobre as cerimônias mortuárias.

A morte de Luis XVIII, em 1824, seria outra ocasião para o uso do rigoroso e anacrônico cerimonial que, com adaptaçóes, remetia a tempos mais gloriosos da história monárquica francesa. Os elementos que compunham os cortejos, a decoração das igrejas e dos altares onde se depositava o caixão, minuciosamente descritos, dão conta do esforço da monarquia no sentido de reavivar os recursos simbólicos que a legitimavam. A tentativa de sacralizar a realeza através da lembrança do martírio de Luis XVI, no entanto, esbarrava na incapacidade do regime de provocar a emoção popular, contaminada pelos ideais da "soberania da razão”. Era impossível, em um sistema representativo, despertar novamente os sentimentos contrastantes de sedução e de medo que sustentavam a monarquia no passado. Assim, a tentativa da fazer de Luis XVI um São Luis II não prosperou.

Mesmo que, durante a Restauração, a cerimônia fúnebre pública fosse um privilégio dos reis, os enterros liberais, beneficiando-se das fímbrias da lei, teriam no período um importante papel político. Regrados pela Prefeitura de Polícia, com um roteiro previamente autorizado, com interdiçáo de coroas e de discursos, tendo os textos das lápides que serem anteriormente aprovados pelas autoridades, mesmo assim esses enterros se constituiriam em espaço de expressão política. Significativamente, foi o enterro de um estudante morto durante uma manifestação de rua em 1821 que deu início à prática do desfile do cortejo fúnebre, dos discursos exaltados à beira do túmulo e das palavras de ordem gritadas à saída do cemitério. Ao longo da década de 1820 , os enterros liberais se rotinizariam e se converteriam numa nova modalidade de participação política, prefigurando um novo repertório de formas de participaçáo.

A própria escolha de alguns pelo enterro anticlerical, isto é, sem a bênção da Igreja Católica, era uma forma de protesto contra a aliança entre o trono e o altar. Por outro lado, a recusa dos sacramentos a mortos que pelo direito canônico estavam proibidos de os receber - comediantes, pecadores notórios que morreram sem terem mostrado arrependimento, pagáos, suicidas e duelistas - provocaria reaçôes que teriam igualmente um caráter político, na medida em que se voltavam contra o poder da Igreja.

Nesse campo o cenário mudaria consideravelmente depois da revolução de 1830 , com a subida de Luis Felipe de Orléans ao trono. A chamada Monarquia de Julho inventou o ritual dos funerais nacionais do homem de Estado e promoveu uma razoável democratização das honras póstumas. Os defuntos celebrados naquele novo contexto respondiam a normas de grandeza ecléticas, por vezes contraditórias, dos insurgidos de 1830 ao homem de Estado, passando pelos grandes generais napoleônicos, os príncipes de sangue e as forças da ordem.

A reaparição ostensiva dos republicanos na cena pública encontraria nos enterros também um espaço de visibilidade. A apresentação de bandeiras tricolores e mesmo vermelhas nos cortejos, a presença de representantes do nascente movimento operário e de exilados estrangeiros de tendência republicana dariam a essas cerimônias um caráter cada vez mais próximo de manifestaçôes políticas quentes. Os enterros franceses, com seus desfiles, suas bandeiras, seus discursos incendiários e seus slogans eram, segundo Fureix, o equivalente dos meetings ingleses e irlandeses. Carregar o caixão no braço, gritar, desafiar o poder e honrar um defunto se tornaram gestos políticos cada vez mais radicais. 
Outra manifestação inédita é a participação cada vez mais ampla de pessoas de diversos estratos sociais nas listas de subscrição pública para fazer construir monumentos fúnebres. Análoga à petição, por promover o cruzamento do individual e do coletivo, do informal e do organizado, do local e do nacional, essa prática se integra, ao longo dos anos 1820, a uma cultura de protesto. A subscrição contorna o monopólio real da homenagem pública e, pela publicação regular dos nomes dos assinantes nos jornais liberais, consagra cada subscritor como um sujeito político.

Nada será mais representativo do emaranhado simbólico do período do que os esforços que a Monarquia de Julho fará para se apropriar do mito de Napoleão. A morte de Bonaparte, em 1821, inicialmente não provocou na França a reação temida pelos Bourbon. No entanto, ao longo daquela década, um verdadeiro culto a Napoleão foi sendo fomentado através de estampas relativas à sua morte que, sendo proibidas pela censura, se valiam de alusóes que acabavam tendo maior poder evocativo até do que a própria imagem do morto. Ao lado das estampas, as cançóes populares, sobretudo as de Béranger, ganharam as ruas na boca do povo, contribuindo para a sedimentação do mito.

A Monarquia de Julho viveria sua primeira década sob a sombra desse gigante. Em 1840, ao trazer de Santa Helena as cinzas de Napoleáo, o regime tentava integrar as referências e os emblemas daquela dinastia rival à história para assim neutralizar seu poder mobilizador. Mas o que deveria ser a festa da soberania tornou-se lugar da manifestação involuntária da pluralidade de opiniôes. $\mathrm{O}$ bonapartismo se dividia, naquele contexto, entre as diversas personas de Napoleão que competiam entre si: o imperador, o general, o legislador e o conquistador que ampliara as fronteiras e os horizontes da nação francesa conviviam com o liberal dos Cem Dias e com o filósofo e o mártir de Santa Helena. Todas essas legendas tinham seus cultores e a elas foram se associando novas, como a republicana e, a partir da releitura que se começava a fazer de 1793 , a do soldado da Revolução. "O luto nacional se tornou um luto plural onde se confrontavam grupos de memória. A despeito do retorno das cinzas, o Napoleáo do povo apelava a uma glória nacional eclipsada pelo pacifismo dominante das elites orleanistas."

Ao produzir essa obra fundadora, Emmanuel Fureix, tal como diz Alain Corbain em seu prefácio, adotou uma forma até agora inédita de escrever história política. Em vez de se deter nos tradicionais estudos sobre as instituiçóes, os mecanismos de decisão e a repartição geográfica e social das decisôes, o autor buscou recuperar uma gama de afetos esquecidos. Deles fez objeto da história, promovendo um mergulho profundo sobre as sensibilidades prevalentes naquele período, revelando como essas se converteram em elementos constitutivos essenciais da ação política. Ao revelar a força mobilizadora dos mortos, Fureix conseguiu "recuperar o momento esquecido em que a morte pública invadiu os desváos da cena pública, onde o luto exprimiu conflitos políticos, onde os cadáveres simbolizavam com força os engajamentos e os combates de cada um". 